\title{
Provisional and Protective Measures in the Draft of the New Hungarian Civil Procedure
}

\author{
LAJOS WALLACHER*
}

\begin{abstract}
This paper presents and analyzes the rules of provisional and protective measures as laid down in the current Draft of the New Hungarian Civil Procedure. It focuses on the purposes and contents of the provisional measures and devotes a separate section to the function of the security that the applicant has to deposit if ordered by the court. The paper concludes that provisional measures have a special mixed character in the sense that they are simultaneously and tightly connected to substantive law and procedural law. The security is regulated in accordance with this mixed character.
\end{abstract}

Keywords: Civil Procedure, Interim Measure, Protective Measure, Provisional Measure, Security

\section{INTRODUCTION}

This paper describes and explains the rules of provisional and protective measures in the Draft of the New Hungarian Civil Procedure (NHCP). Certain principles and characteristics of Hungarian law will also be touched upon as it is useful from comparative law perspective to set the context.

It was the decision of the Hungarian Government to charge the Preparatory Committee with the task of improving and clarifying the existing law, i.e. the provisions of the Act of 1952 on Civil Procedure. ${ }^{1}$ It was not an over-ambitious plan as this topic fell outside the spotlight of the preparatory work, so it was not something that was supposed to be a distinguishing feature or design to the NHCP.

What were the fields where the improvement and clarification seemed to be necessary? The answers to this question can be found in the case law and in the legal literature. However, it would fall outside the aims and scope of this paper to describe and thoroughly analyze these sources in a detailed manner. Nevertheless, it is useful to take a brief look at the topics dealt with in the academic literature and the problems crystallized in the case law.

Regarding the legal literature, a researcher can realize that the authors were focusing mainly on the cross-border aspects of provisional (interim) measures. The authors paid particular attention to the legislation of the European Union relating to provisional (interim) measures. $^{2}$ The need for effective protection of the intellectual property rights, which are extensively regulated in international treaties and by EU law as well, also brought provisional measure into focus. ${ }^{3}$ The demand for effective protection of intellectual property

* Attorney at law, Squire Patton Boggs Budapest, associate professor at University of Pécs, Hungary. E-mail: lajos.wallacher@scquirebp.com

1 See the resolution of the Hungarian Government adopted on 14 January, 2015 on the Concept of the New Civil Procedure at http://www.kormany.hu/download/f/ca/30000/20150128\%20Az\%20 $\% \mathrm{C} 3 \% \mathrm{BAj} \% 20$ polg$\% \mathrm{C} 3 \% \mathrm{~A} 1 \mathrm{ri} \% 20$ perrendtart\%C3\%A1s\%20koncepci\%C3\%B3ja.pdf accessed 6 June 2017.

2 See, e.g. Osztovits (2010) 18-24; Wopera (2000) 50-53; Wopera (2001a) 213-21; Wopera, (2001b) 743-51; Wopera (2002) 15-21; Wopera (2003) 227-33; Wopera(2009) 19-35; Szekeres (2001) 22-28; Horváth, (2014) 78-85.

3 See, e.g. Vida (2007) 389-400; Bércesi and Kecskés (2001) 537-47; Bächer, (1991) 544-49; Wopera (2011) 142-60. 
rights exerted massive influence on the procedural legislation. The intellectual property rights played important role in shaping the procedural rules relating to provisional measures because after 1989 the developing international trade required more effective protection of intellectual property rights. Traditionally the courts were reluctant to order provisional measures which subsequently triggered legislative intervention to encourage wider use of these procedural tools to satisfy the needs of international commerce. ${ }^{4}$ The lack of widespread application of provisional measures attracted general criticism. ${ }^{5}$ Due to the scarcity of court ordered provisional measures, Professor Zsuzsa Wopera, the most cited author and leading expert in this field, called the actual application of provisional measures "marginal". ${ }^{6}$ Indeed, there have been few reported cases to date and most of them deal with procedural details e.g., appealability ${ }^{7}$, the applicable standard of proof ${ }^{8}$, ex parte proceedings ${ }^{9}$. The commentaries also concentrate on these procedural particularities ${ }^{10}$.

In the light of the case law and the comments made in the legal literature the Preparatory Committee identified three ${ }^{11}$ key issues in relation of which the current procedural rules for provisional measures should be amended or modified for the sake of clarification and/or improvement. The targets of this re-regulation process were $i$ ) purpose(s) served by provisional and protective measures; ii) contents of the provisional and protective measures; iii) the security to be deposited by the applicant. Each topic will be expanded in the following sections..

\section{PURPOSES SERVED BY PROVISIONAL AND PROTECTIVE MEASURES}

The very first question to answer was simple - what are these measures for? Prima facie this seems to be a simple question but the answer is not so obvious once it is realized that it implies two other questions - In which circumstances may be such measures ordered, and on what conditions? - In other words, from what do provisional measures protect the parties?

The explanatory statements attached to the NHCP make it very clear that provisional and protective measures are not intended for (i) obtaining/preserving evidence, (ii) freezing/ securing assets or (iii) early satisfaction of the claim.

\section{Excluded matter (i): obtaining/preserving evidence}

It is crucial for the parties to obtain the relevant evidence when seeking to substantiate their claims. Effective evidence gathering is of utmost importance for the proving party. It is also in the interests of the judicial system to give the parties adequate and equal procedural tools to obtain the necessary evidence. It is well known that individual rights are worthless

4 The Parliament made it almost compulsory "highly recommended" to order provisional measures if the protection of intellectual rights were at stake - see Act XI of 1997.

5 Nehéz-Posony (2011) 37-38.

${ }^{6}$ Quoted by Kapa (2008) 446-47.

7 Judgment of the Supreme Court published as BH2006.254.

8 Judgment of the Supreme Court published as BH2000.406.

9 Judgment of the Supreme Court published as BH2003.110.

10 See e.g. Osztovits et al. (2013) 331-32 and Czoboly et al. (2013) 231-33.

11 In this paper I will not cover the fourth issue, which was quite simple: the current rules do not allow parties to request provisional measures before commencing the lawsuit, although it would make sense from a practical point of view. Therefore the NHCP repeals this rule. 
without procedural instruments through which these rights may be enforced effectively. Enforcement of rights requires the establishment of facts which support the claim. Sometimes it can be a burdensome task so the parties are in need of help to obtain the necessary evidence.

The NHCP provides special procedural tools to this end. One is the preliminary taking of evidence which helps preserve the evidence even before the commencement of the lawsuit. This mechanism aims to secure the timeliness of evidence taking. In other words, it tries to prevent the harms that could be caused by the passage of time.

The other type of procedural tool the NHCP offers has nothing to do with the time aspect of evidence taking. Rather, it tackles the problem when the party who bears the burden of proof does not possess the evidence needed to achieve this goal. The NHCP does not devise a system that would remind us of the discovery, but provides special and limited procedural rights for the party who is not capable of supporting their allegations with adequate evidence.

Thirdly, it is worth mentioning that sometimes the substantive law itself provides ancillary rights aimed at information gathering. For example, in the field of intellectual property rights the right of information evolved as a procedural limb of the substantive rights. ${ }^{12}$

\section{Excluded matter (ii): freezing/securing assets}

It is also important for the plaintiff to have adequate tools to secure the assets out of which the final judgment could be satisfied. However, Hungarian law qualifies tools of this type as enforcement devices, so it is regulated in a separate act. These tools may be used by those parties who have in their hands convincing evidence e.g., written documents to which the law attaches special evidentiary weight.

It is worth mentioning that numerous instruments of substantive civil law directly or indirectly also pursue this aim e.g., share capital requirements, pledge, suretyship, etc.

\section{Excluded matter (iii): early satisfaction of the claim}

According to the NHCP, pure need for urgency does not justify provisional measures, especially in relation to monetary claims. However, there are certain exceptions, e.g. maintenance claims based on family law provisions.

After surveying the excluded matters we can proceed to the purposes recognized by the NHCP, that is to say, to those cases when the courts may order provisional measures (the positive list).

\section{The positive list: situations when provisional measures may be ordered}

The NHCP allows the parties to request provisional measures in order to achieve the following goals: $i$ ) to prevent imminent harm; ii) to prevent the frustration of later exercise of rights; iii) to preserve the status quo - to prevent irreversible changes. ${ }^{13}$

12 See Article 8 of the Directive 2004/48/EC of the European Parliament and of the Council of 29 April 2004 on the enforcement of intellectual property rights.

13 This rule is quite similar to the current one (Section 156 of the Civil Procedure Act) which reads as follows: 'The court, upon request, may implement provisional measures ordering satisfaction of the claim (counterclaim), or compliance with the application requesting provisional measures, 
These cases have one common feature; disadvantageous events would happen without the measure and thus something should be done to prevent this. There is a need for protection (for a protective measure). The protective measures are provisional in the sense that the final judgment, if delivered in favor of the applicant, will solve the problem but the applicant cannot wait until that time. There is no explicit reference to urgency, but one can say that this condition is implied - without timely intervention the harm, frustration or irreversible change could become reality.

\section{CONTENTS OF THE PROVISIONAL MEASURES}

The case law of the courts has revealed that the Civil Procedure Act $^{14}$ does not give a straightforward answer to the question of what contents may be included in a provisional measure. The courts interpreted the law differently, ${ }^{15}$ so the Preparatory Committee came to the conclusion that to ensure the uniform interpretation of the law this question should be decided explicitly, with unequivocal wording. There were three possible solutions.

The contents of the measures could be described in the following ways: $i$ ) the applicant may request as a provisional measure that the other party should do something or should refrain from doing something (formal answer); ii) the provisional measures may include only those acts/behaviors that can be derived from substantive rules (close-ended model); iii) anything may be ordered that is practically possible, without limits (open-ended model).

The formal answer should be rejected because it does not offer a genuine solution. The close-ended model would correspond to the concept relating to the relationship between substantive law and procedural law. This can be explained by highlighting the relationship between substantive law and procedural law, as understood by Hungarian lawyers. Under Hungarian law, it is the substantive law which defines the possible claims and remedies the very essence of the substantive right is the range of claims that follow from the right in question. Therefore procedural law, in general ${ }^{16}$, does not regulate the individual contents of different types of claims. The attitude of procedural law is similar to that concept we described above as formal answer: it is required from the plaintiff to formulate the claim as a request addressed to the court to oblige the defendant to do something or to refrain from doing something.

The open-ended model would result in the establishment of new substantive rights for the duration of the litigation, just because of the fact that a lawsuit had been filed. This new right would cease to exist if the applicant lost the case on the merits. This new right would be granted in the consideration of security.

After carefully observing the text of NHCP, we can conclude that it devises a mixed model.

where this is deemed necessary to prevent any imminent threat of damage, to preserve the status quo giving rise to the dispute, or with a view to underlying the requirement for the special protection of the applicant's rights, where the advantages to be gained must always supersede the disadvantage obtained by the measure.' (Non-official translation provided by Ügyvéd Jogtár.)

14 Act III of 1952 on the Civil Procedure.

15 See e.g. the judgments published as BH2002.441 of the Supreme Court, BDT2007.1695 of the Court of Appeal of Pécs, BDT2016.3532 of the Municipal Court of Appeal.

16 There are exceptions, e.g. the declaratory actions regulated by Section 123 of the Act on Civil Procedure. 
From the perspective of procedural law, it can be said that the court orders the party to do something or to refrain from doing something. This, however, does not mean that anything can be ordered, anything that is conceivable, so to say, under the sun.

Rather, the NHCP seems to prefer the close-ended model. As we described above, the concept is that a plaintiff may claim only those courses of action to be carried out by the defendant that are provided for in substantive law. It is the substantive civil law which determines the contents of the claims and, as a corollary, the contents of the judgments. Consequently, the procedural law has no say in this matter - the contents of the provisional measures are regulated by substantive rules.

Thus, it has been shown that the choice of the NHCP seems to be that the contents of the provisional measure must be derived from the substantive rules. However, it can be argued that the positive list of situations where provisional measures may be ordered, according to the NHCP, predicts measures with such contents that have nothing to do with substantive law - substantive law typically does not grant such rights as preserving status quo or saving other future rights.

This argument is well-established and thus the prima facie conclusion, regarding the classification of the model chosen by the NHCP, should be reconsidered. This regulation is like a mythological being, a mermaid, that is half human half animal, half woman half fish. It is a mixed model because the provisional measures have substantive and procedural law characteristics at the same time.

Provisional and protective measures have their roots in the substantive law, but they should be qualified as sui generis substantive rights which manifest themselves only in procedural rules ${ }^{17}$. These measures are provisional because they will become superfluous once the final judgment is delivered. If the judgment is properly executed, there will be no need for the measure. If the applicant attains their goal i.e., wins the case, the situation that will come into being as a consequence of the judgment makes any further protection needless. The provisional measures function as an advance, precautionary protection tool. They are special procedural extensions of the substantive rights because the measures add something extra to the contents of the substantive rights (preventing imminent harm, preserving status quo, saving future rights).

This dual nature of the provisional measures explains the wording that the contents of the measures should be "derived from" the substantive law, instead of "written in", or "prescribed by". As to the nature of the connection between the measure and the substantive right, we can establish hardly any general principle. Some link must exist between the substantive right enforced by the applicant on the one hand and the contents of the measure. This relationship may be direct or indirect, close or remote. The type of the connection does not really matter, but the applicant must explore some kind of link. It is inevitable because of the need for legal certainty. Without this link the provisional measure could spill over the boundaries set by the rights that the plaintiff seeks to enforce.

When slicing and dicing the procedural rules of provisional measures, it must be realized that procedural law creates something akin to a new substantive right e.g., the right to maintain the status quo, and the only reason for this is the commencement of the lawsuit. Without litigation, one has no right to maintain the status quo, but once a plaintiff brings an

17 One short remark here: I think that it is this mixed nature of the provisional and protective measures in some jurisdictions that is responsible for the troubles faced during the application and interpretation of the relevant rules of the Brussels I. Regulation. 
action, they acquire this special right. The NHCP grants this right not because of the lengthiness of the lawsuit, it is enough if the litigation lasts longer than a heartbeat. If the plaintiff asserts their rights before a court, they get an additional right. The court, when decides whether to grant this special right should take into account whether the advantages to be gained through the measure supersede the disadvantages caused by the measure. The protection is urgent in the sense that without it the efficacy of the substantive right could be severely impaired. However, it is a very special right - it seems autonomous, ceases to exist once the applicant loses the case on the merits. This means that the final legality of the measure depends on the outcome of the case. Moreover, there is price tag attached to these new rights - it is called security.

\section{THE FUNCTION OF THE SECURITY}

The rationale behind the security is obvious. It is to compensate the defendant for any loss/ damage they could suffer by reason of the provisional measure. During the preparatory work, two related questions have emerged: How should the amount of the security be determined? What kind of procedure should be applied in order for the defendant to realize the compensation? The NHCP gives clear answers to these questions.

The NHCP prefers and facilitates the consensus of the parties to settle the determination of the amount of the security. The reason for this attitude is that the courts have power to order the applicants to post security. The aim of the security is to compensate the defendant for any loss/damage they could suffer by reason of the provisional measure. Security is needed if the defendant shows that they could probably suffer harm due to the measure. They does not have to prove actual harm, it is enough to present a prima facie case. However, even this exercise may be time consuming and requires an adversarial procedure instead of inquisitorial role to be played by the court. That is why the draft prefers a consensual scheme. There is no need to decide on the probability of the harm and the amount of the security if the parties agree on the amount of the security. The applicant will have an incentive to agree by urgency and the other party also will have an incentive - the fear of failure in establishing the probability of the harm.

The remaining question is "if the defendant wins the case, how can they realize the compensation?" The NHCP says that no additional procedure is needed - the defendant obtains the security directly, without the need to prove any actual harm or damage. However, they can claim additional damages in a separate lawsuit. First and foremost this is a practical solution. The procedure is fast and simple, there is no room for an ex post debate over the amount of the security. Moreover, this solution also sheds light on the special nature of provisional measures - the procedural law establishes a special, additional right which has its own price. This price is independent of the substantive right the applicant seeks to enforce.

\section{CONCLUSIONS}

The experts who drafted the NHCP were charged with the task of clarifying and improving the existing law to meet the demands of the legal practice and theory. To this end they have re-regulated the possible contents of the provisional measures, and the security, especially the method through which the defendant can swiftly and simply realize the compensation secured by the security. The new scheme makes it clear that the procedural law creates a special phenomenon that is similar to a new substantive right, especially the right to 
maintain the status quo. This can be characterized as a special extension of the substantive rule in question. The contents of the provisional measure should be traced back to the substantive rule that the applicant actually seeks to enforce and tightly connect to this substantive rule but it is clearly more than that. The way the NHCP regulates the security mirrors this special character of provisional measures.

\section{LITERATURE}

Bächer, V., 'Az ideiglenes intézkedés a szabadalombitorlás és utánzás esetében a magyar joggyakorlatban' (Interim measures in the case of patent infringement and counterfeiting in the Hungarian courts' case-law) (1991) 9 Magyar Jog 544-49.

Bércesi, Z., and Kecskés, L., 'A törvényi védelem és az ideiglenes intézkedés alkalmazásának lehetőségei és problémái szabadalombitorlás miatt indított perekben' (The prospects and problems of the application of legal protection and interim measures in court cases for patent infringement) (2001) 9 Magyar Jog 537-47.

Czoboly, G., Juhász, L., Kengyel, M., Király, L., and Nemessányi, Z., Polgári eljárásjog (Civil procedural law) (Dialóg Campus 2013).

Horváth, B., 'A Brüsszel I. rendelet alkalmazhatósága az európai versenyjogi jogsértésekkel kapcsolatos kártérítési keresetek kapcsán hozott ideiglenes intézkedésekre' (The applicability of the Brussels I Regulation to interim measures adopted in respect of damages actions for breach of the EU competition rules ) (2014) 2 Versenytükör 78-85.

Kapa, M., 'Jogvédelem és ideiglenes intézkedés. Recenzió Wopera Zsuzsa "Hatékony jogvédelem a magyar és az Európai Unió polgári eljárásjogában” címü monográfiájáról' (Legal protection and interim measures. Review on Zsuzsa Wopera's monograph entitled "Effective legal protection in Hungarian and European Union civil procedural law") (2008) 6 Magyar Jog 446-47.

Nehéz-Posony, M., 'Ideiglenes intézkedés: van, de nincs' (Interim measures: they exist, but to no avail ) (2011) 5 Ügyvédek Lapja 37-38.

Osztovits, A., 'Ideiglenes intézkedések a határokon átnyúló szülői felelősséggel kapcsolatos perekben - az Európai Unió Bíróságának legújabb joggyakorlata tükrében' (Interim measures in court cases concerning cross-border parental responsibility - in the light of the latest case-law of the European Court of Justice ) (2010) 4 Családi Jog 18-24.

Osztovits, A., Pribula, L., Szabó, I., Udvary, S., and Wopera, Zs., Polgári eljárásjog I. (Civil Procedural Law I.) (HVG-ORAC Budapest, 2013)

Szekeres, Sz., 'Az ideiglenes és biztosítási intézkedések jogharmonizációs szempontú vizsgálata' (The analysis of interim and protective measures from a legal harmonisation point of view) (2001) 4 Európai Jog 22-28.

Vida, S., 'Ideiglenes intézkedés védjegybitorlási ügyekben' (Interim measures in cases for trade mark infringement) in Harsági, V. and Wopera, Zs. (eds), Az igazságszolgáltatás kihívásai a XXI. században: tanulmánykötet Gáspárdy László emlékére (HVG-ORAC, Budapest, 2007) 389-400.

Wopera, Zs., 'Az ideiglenes intézkedés szabályozásának várható tendenciái az Európai Unióban' (The expected trends of the regulation of interim measures in the European Union) (2000) 1 Magyar Jog 50-53.

Wopera, Zs., 'Európai körkép egyes államok polgári eljárásjogának ideiglenes intézkedéseiről' (A European overview of interim measures in the civil procedural laws of certain Member States) (2001a) 5 Jogtudományi Közlöny 213-21.

Wopera, Zs., 'Az ideiglenes intézkedések a Brüsszeli Egyezmény 24. cikkére vonatkozó európai bírósági joggyakorlat tükrében' (Interim measures in the light of the European courts' case-law) (2001b) 12 Magyar Jog 743-51.

Wopera, Zs., 'Az ideiglenes intézkedés szabályozása az Európai Unió egyes jogforrásaiban' (The regulation of interim measures in the European Union's sources of law) (2002) 4 Európai Jog $15-21$.

Wopera, Zs., 'Az ideiglenes intézkedés perjogi intézményének elméleti megközelítési lehetőségei' (Options for a theoretical approach to the procedural legal instrument of interim measures) (2003) 5 Jogtudományi Közlöny 227-33. 
Wopera, Zs., 'A határon átnyúló ideiglenes intézkedések. Reflexió a Brüsszel I. rendelet alkalmazásáról szóló 2007. évi Jelentés megállapításaira' (Cross-border interim measures. Reflection on the findings of the 2007 report on the application of the Brussels I Regulation) in Wopera, Zs. and Asztalos, Zs. (eds), Egységesülő polgári eljárásjog Európában. Tanulmánykötet (2009) 19-35.

Wopera, Zs., 'Az ideiglenes intézkedés speciális szabályozása a szellemi tulajdonvédelem területén' (The special regulation of interim measures in the field of the protection of intellectual property) in Barzó, T. (ed), A szellemi tulajdon. Az Állam- és Jogtudományi Kar által 2010. június hó 4. napján „A szellemi tulajdon védelme” címmel szervezett konferencián elhangzott elöadások alapján készült tanulmányok gyüjteménye (Miskolc, Bíbor 2011) 142-160. 